\title{
“Corruptocracy" Harms High Performing Faculty in Engineering Education
}

\author{
Thanikachalam Vedhathiri \\ Former Professor and HOD, Center for International Affairs, National Institute of \\ Technical Teachers Training and Research, Chennai, India \\ vthani2025@gmail.com
}

\begin{abstract}
Higher education growth is based on supporting the high-performing faculty teams. If they are denied resources, funds, and autonomy, they can't contribute to the knowledge capital. In the last 25 years, many corrupt Chief Executive Officers (CEO) of higher education in India have been suspended and the cases were filed in various courts. The CEOs got the posts due to a weak selection process. Based on this research, a theory on "Corruptocracy" has been synthesized which describes the corrupt and unethical administration by the corrupt CEOs who institutionalized the corrupt practices. Many of the high achieving faculty members are not able to contribute to the knowledge capital and move up in their career ladder due to "Corruptocracy". This is due to poor governance. The research is based on the data collected from 540 faculty members over 50 years using a naturalistic evaluation model. The research results provided important findings on the performance of the higher education institutes like slow growth, the suffering of outstanding faculty members, negligible contribution to knowledge capital due to not developing new programs \& projects, and not focusing on the human and knowledge capital. The CEOs control the development of human and knowledge capital and give the highest priority to self and coterie development. The unethical administration has to be checked scrupulously through the conduct and institutional governance rules. The Board has to get six-monthly feedback from the faculty members and correct the deviations which will accelerate the output of quality knowledge and human capital. Considering the need for an outstanding CEO, further research is recommended.
\end{abstract}

Keywords: Corruptocracy, Poor governance, Loss to the high-performing faculty members, Loss of knowledge, Human capital development, Academic audit, Performance audit

\section{Introduction}

Most of the countries have been very affected by corruption in higher education. Many degree-awarding factories give bogus doctoral degrees. Many get promotions even without minimum prescribed qualifications leave alone global research publications or innovations. Many prospective CEOs have used money or political connections to achieve their goals. They create a group of coteries to protect them. They also curb the growth of competent and well-performing faculty members. They develop strategies to elevate their coteries who lack

Article history:

Received (March 8, 2021), Review Result (April 5, 2021), Accepted (June 10, 2021) 
qualifications and expertise. This is affecting the growth of knowledge capital and human capital. The country has to depend on foreign technologies.

Under these circumstances, it is planned to undertake detailed research on the phenomenal growth of corruption in higher education, the root causes, and the cancerous growth of academic corruption which affects the knowledge capital and human capital. Max Weber, a German Sociologist identified the working, recruitment, decision making, and promotion of the people in the government. His study gave rise to a model called "Bureaucracy" which has been well recognized in all cultures.

\section{Objectives of the research}

The corruption in autonomous institutes is deep-rooted and they need to be identified and then only one can suggest various control measures to eliminate them. The following are the objectives of the research:

(a) To assess the growth of corruption in higher education due to CEOs.

(b) To analyze the information on the ongoing corrupt practices in autonomous institutes using the natural research process.

(c) To develop a model "Corruptocraphy" for the institutionalized corruption in higher education.

(d) To identify the strategies to control and eliminate corrupt practices in autonomous institutes.

(e) To suggest the most promising global practices to ensure academic ecosystem which will accelerate the human capital development and ultimately knowledge capital development to sustain the growth of the economy.

\section{Research methodology}

The performance, decision making, the impact on the knowledge capital development and human capital development due to twenty-five CEOs have been followed and reviewed based on the best practices of higher administration principles over fifty years. The naturalistic evaluation model of Guba and Lincoln (1989) has been adopted which is qualitative research based on the observations and verification from three other sources. Further, the significant deviations were recorded and analyzed.

\subsection{Data collection}

540 faculty members have been consulted over 40 years and their feedback on the performance of 20 CEOs has been verified using the triangulation method. The discretions of the CEOs were analyzed through the feedback of 540 faculty members. The growth of the institutions and the performance of the graduates have also been critically examined. The overall contribution and the shortcomings have been reviewed and the refined development process has been brought out. 


\subsection{Research questions}

The following are the significant research questions considered for this paper:

(a) Whether the autonomous institutions enable unlimited freedom to corrupt CEOs to take key administrative decisions using their discretion?

(b) What are the backgrounds and significant accomplishments of the poorly performing CEOs?

(c) What are the visible modes of operation of the corrupt CEOs to institutionalize their unethical activities?

(d) Whether the high-performing faculty teams are harmed by the corrupt CEOs?

(e) Whether the institute is significantly contributing to the knowledge capital and human capital?

(f) Whether the Board of Governors fix the vision, mission, and goals in academic programs and achievement?

(g) Whether the Board of Governors aware of the policies and direction of the government?

(h) Whether the Board is aware of the shortfalls in achieving the mission by the institute?

(i) Whether the Board of Governors monitor the deviations adopted by the CEOs from the established laws, rules, or acts in the administration?

(j) How can the Board eliminate the institutionalized corruption in the institute?

\section{Literature survey}

Research studies on corruption in higher education attracted the attention of the researchers [1-17], [19-33], [34][35][36][37][38][39][48][53], [56-64]. Engineering education is a major driver in economic development. It strengthens industrialization and GDP. Philip Coombs (1968) [20], then Director of International Institute of Educational Planning (IIEP), identified the deficiencies in education. According to him often quality is low, efficiency is weak, relevance questionable, and wastage significant, while aims and goals are frequently unclear. He brought out a book entitled "The world educational crisis. IIEP launched research in 2001 on 'Ethics and Corruption in Education' The project was based on (i) examining country experiences that would result neither in fatalism nor in despair, but rather the conviction that many significant and successful strategies can be adopted to reduce corruption and improve governance in education. (ii) the challenges and difficulties are not confined to the developing world. Bray [26], Director, IIEP stated that academic fraud is regarded as a serious threat to the integrity and reliability of certification in higher education, leading to skepticism as to the validity of results and suspicion about real performance. Distorting decisions in procurement for the education sector are prevalent throughout the world. According to him the most effective strategies for improving governance, transparency in education is based on:

(i) Improving regulatory systems;

(ii) Strengthening managerial capacities, and

(iii) Building social control over the use of resources. 
According to him, in addition to exploring, identifying, and scrutinizing successful strategies to curb corruption is looking into how to implement changes. Further, the measures to counteract corruption mobilize vested interests that actively resist change, circumvent decisions and sometimes obstruct implementation.

According to Bray [26], the following are some of the successful measures:

(a) Improving the management of teachers and reducing the wastage in resources will be possible by combining negotiations with teachers' unions, transparent regulations, and modernizing using informatics.

(b) Reducing leakages in the transfer of funds and dissemination of detailed information to communities

(c) Publishing penalties have been taken against officials guilty of distorting implementation

Reducing fraud in entrance examinations to higher education by using informatics to eliminate any possible interference in administering, checking, or publishing exam results.

Kusum et al. [26] observed that many Indian educational institutions have their primary emphasis on money-making and materialism instead of on the concept of human capital development. According to the privatization of education, teacher appointments, posting, transfer and stay at a choice of place, teacher absenteeism from classes, private tutoring, midday meal, admission process, examination process-cheating, unfair means act, practical examinations, result, an affiliation of institutes, student scholarship, purchasing and maintenance in institutes, etc. This shows that all the educational systems are very much affected due to uncontrolled corruption which is supported by invisible politicians.

Deepa [12] listed a set of corrupt vice-chancellors who have been arrested by the Directorate of Vigilance and Anti-Corruption. A few notable cases are VCs of Bharathiar University, Tamil Nadu Agricultural University, Babasaheb Bhimrao Ambedkar University in Lucknow, and Vidyasagar University, West Bengal.

Hallak et al. [19] Engineering education is prone to corruption. Ararat [5][6] predicted that is corruption essentially needed to sustain human capital. Aisba Labi (2013) traced the history of corruption in higher education. Many forms of corruption affect the national growth in human capital. Many deep-rooted corruptions can't be visible but they make the educational system completely collapse. Such phenomena are called "Corruptocracy" which is the outcome due to the personal development-based decision-making of the CEOs. Due to this, the programs are affected and the coterie alone survives and grows. The funds are rarely utilized for academic purposes but they are trained to meet the personal goals of the corrupt CEOs. The building construction, purchases, research contingencies, fellowships, gains from the projects, building maintenance funds, etc. are all diverted skillfully, when we follow a set of 25 corrupt CEOs, we get the inner practices, the drawbacks in the decision making and the protection that these CEOs make.

\subsection{Bureaucracy}

Weber [28] German Sociologist defined bureaucracy as a highly structured, formal, and also impersonal organization. Bureaucratic organizations possess the following characteristics (Richard Hall [37]):

(a) A division of Departments, Centers, Units, etc. based on functional specialization; 
(b) A well-defined hierarchy of authority (Vice-Chancellor, Director, Dean, Professor, Associate Professor, Assistant Professor, Senior Scientific Officer, etc.);

(c) A system of rules covering the rights and duties of faculties (Promotion, Selection for Foreign Deputation, Approval for Presenting Papers in International Conferences, Awarding Higher Administrative Position, Funding for Projects, etc.);

(d) A system of procedures for dealing with work situations (Curriculum Development, Publication, Research \& Development, Undertaking Consultancy Projects, etc.);

(e) The impersonality of interpersonal relations (Ranking based on the accomplishments, Maximum Qualification, Years of Experience, etc.);

(f) Selection and promotion based only on technical competence (Highest Qualification in the branch of engineering, Services Rendered, etc.).

The university faculty of various programs should have the highest qualification and experiences as per the University Grants Commission (UGC) All India Council for Technical Education (AICTE), and Service Recruitment Rules of the Society. The institutes are governed by well-defined rules of the Government/ UGC/AICTE. The activities of any educational department have to follow the rules. There is no room for partiality or discretion for decisions. Even though all these are applicable, the institutes fail to achieve desired human and knowledge capitals.

Michael Raymond Heilmann [32][33] analyzed Principals Perspectives on Discretion and Decision-Making). He presented a new conceptual model for discretion.

According to Global Corruption Report, "Education reveals that corruption for resources, fame and notoriety place extraordinary pressures on higher education institutions. In some instances, corruption has invaded the whole system of higher education and threatens the reputation of research outputs and graduates, regardless of their guilt and innocence. Educational corruption appears to be rampant in Africa, Asia, Australia, Europe, America, and Russian Federation. In May 2015, South African Authorities shut down 42 bogus colleges and universities that were offering degrees in 15 days. They are termed "degree mills" (Osipian Ararat, 2008) [5][6]. In many African countries frequent corruption occurs in recruitments, promotions, falsified research works for publications, fake journals obligating students to buy textbooks written by faculty. Some faculty members indulge in extortion of money for marks and sexual harassment. A sizable percentage of students plagiarize, fabricate references, collude in examinations to communicate answers. Some impersonate examinees. Some private universities set up branch campuses in various developing countries and admit students without adequate qualified faculty members. In many developing countries the sale of fake degree certificates has been deducted. Corruption not only hurts the students but also undermines the educational quality. It provides inequitable access to careers. If the reputation of the university's once lost, it can't be retrieved for many decades.

Vanessa Valentino (2007) [58] lists methods of managing corruption in Moldova. According to her, the Ministry of Education and Youth (MET) in Moldova become more active in addressing academic corruption. An action plan to prevent and combat corruption in the educational system was authorized in collaboration with the Centre for Combating Economic Crime and Corruption. The study focused on cheating and bribery for grades. The corruption is due to poor student and teacher quality, low effective penalties, and limited relevance of knowledge and skills acquired through education. The MET developed a standardized national entrance examination and outsourced state examinations to an independent external agency. 
Mohamedbhai [14] concluded that it is high time now to declare war on corruption in higher education. Many global organizations are addressing some of the issues, such as UNESCO's International Institute of Planning (IIEP) and the US-based Council for Higher Education Administration (CHEA). Bribery, fraud, embezzlement, nepotism, and favoritism are commonly used terms (United States Institute of Peace). Bribery, an offering of something of value for some action in return, is an example of corruption. Other terms associated with corruption include fraud (using a trusted to deceive for profit) embezzlement (theft of government resources by those in authority), nepotism (favoritism is shown to friends or relatives by those in power). While corruption can include all of these terms, it is not just financial gain; there can also be political and legal gains that often include exclusive access to decision-makers, political and legal authorities. Favoritism is practiced widely, but there is no exchange of money, it is not legally considered bribery. A favor is simply expected in return at some later stage. It may be a favor granted in return for political support or an appointment to a position. Such preference treatments given to friends, relatives, or business partners are very common in some cultures, but some argue that such practices undermine the concept of fair play.

Thanikachalam [43][44] focused on enhancing institutional governance beyond the Society's Act of 1860. He recommended to the performance of the autonomous institutes should be checked through the Board of Governors. He further suggested building the institute's culture and values to facilitate high performance. Thanikachalam [45][46][47][48][49][50][51][52][53] explored the performance management and turnaround mechanism of poorly performing institutes. He recommended building an appropriate educational management ecosystem for developing the professional competence of CEOs in higher education. According to him, academic excellence can be improved through faculty engagement and an appropriate ecosystem. He also presented strategies for eliminating corruption in engineering education and fostering excellence in human capital development. Fast-growing educational institutes can be supported by a desired educational ecosystem. To undertake international consultancy projects by the engineering institutes, an advanced educational system is a must. The CEOs have to establish dynamic processes to enhance the faculty competence in engineering institutes. All these need to be studied in many autonomous colleges. The CEOs and the Board of Governors are responsible to create a suitable ecosystem but many institutes do not perform well. The causes for low performance can be identified when the decisions made by the CEOs and the resulting status. The affiliated colleges do not give room for discretion to the CEOs. The achievement is watched regularly. The rules are to be followed scrupulously. In the case of autonomous colleges, more authority is delegated to the CEOs and they are governed by the Board. In this process, many corrupt CEOs join the institute bypassing the excellent candidates. They create a haven for all unethical activities. Many PILs were submitted to the courts and finally, the corrupt CEO is punished but many losses occurred to the system. An early deduction is very essential.

\subsection{Summary of the literature}

(a) Corruption is widespread in higher education in many countries

(b) Creates a serious threat to the integrity of certification in higher education

(c) The most effective strategies for improving the performance of the autonomous institutes are on the improving regulatory systems

(d) Problems of Autonomous colleges center around the ineffective Boards 


\section{Study of CEOs' background}

20 CEOs have been followed through a naturalistic evaluation process suggested by Guba and Lincoln [17]. Around 200 faculty members have been consulted over 20 years period. Their viewpoints are checked with other sets of faculty members through the triangulation method (Kennedy Patrick [24] Triangulation-Better Evaluation, 2018).

\subsection{Definitions}

State University: established by an act of state assembly, but has to follow the UGC rules for planning educational programs in arts/ science/ commerce/business administration, etc. In the Engineering programs, the AICTE rules are to be followed.

Autonomous Institute: Established by the central government under the Society's Act of 1860. It will be governed by a Board of Governors and it has registered a Memorandum of Activities. The Society prescribes Service and Recruitment Rules. Besides, all the Financial Rules and Conduct Rules are to be followed.

Autonomous Institutes are also approved by the University based on the performance, faculty qualification, adequacy of the faculty, and resources under UGC or State Board of Technical Education.

The recruitment of the faculty should be based on the UGC/AICTE/Service and Recruitment Rules. There is no discretion to tone down the qualification or experience.

High performance includes the number of Ph.D. scholars guided, publications of original papers in the international journals and conferences, consultancy projects completed, contribution to the institutional development through internal revenue generated. The contribution to knowledge capital is recognized through global recognitions, rewards, fellowships by the universities, professional associations, and Foreign Governments.

Political influence is obtained to force the decision-making bodies to select a candidate who is not qualified and experienced and disregard the highly qualified candidates.

The outcome is presented in [Table-1].

Table 1. CEOs' background

\begin{tabular}{|c|c|c|c|c|c|c|c|c|}
\hline CEO & Ph.D. & $\begin{array}{l}\text { Type of } \\
\text { Institution }\end{array}$ & $\begin{array}{l}\text { Ph.D. } \\
\text { Guidance } \\
\text { Up to } 15\end{array}$ & $\begin{array}{c}\text { Facilitated } \\
\text { Postgraduate } \\
\text { Programs }\end{array}$ & $\begin{array}{l}\text { Facilitated } \\
\text { Global } \\
\text { Consultancy } \\
\text { Projects }\end{array}$ & $\begin{array}{l}\text { Outstanding } \\
\text { Global } \\
\text { Recognitions }\end{array}$ & $\begin{array}{c}\text { Institute. } \\
\text { Develop } \\
\text { ment. }\end{array}$ & $\begin{array}{l}\text { Political } \\
\text { Influence }\end{array}$ \\
\hline 1 & Yes & $\begin{array}{c}\text { State } \\
\text { University }\end{array}$ & No & Yes & Yes & Yes & Yes & Strongest \\
\hline 2 & Yes & $\begin{array}{c}\text { State } \\
\text { University }\end{array}$ & Yes & Yes & No & Moderate & Yes & Strongest \\
\hline 3 & No & $\begin{array}{l}\text { Autonomous } \\
\text { Institute }\end{array}$ & No & No & No & Nil & Partial & Strongest \\
\hline 4 & No & $\begin{array}{l}\text { Autonomous } \\
\text { Institute }\end{array}$ & No & No & No & Nil & No & Strongest \\
\hline 5 & Yes & $\begin{array}{l}\text { Autonomous } \\
\text { Institute }\end{array}$ & No & No & No & Nil & No & Strongest \\
\hline 6 & Yes & $\begin{array}{l}\text { Autonomous } \\
\text { Institute }\end{array}$ & No & No & No & Minimum & No & Strongest \\
\hline 7 & Yes & $\begin{array}{c}\text { Autonomous } \\
\text { Institute }\end{array}$ & No & Yes & Yes & Nil & No & Strongest \\
\hline 8 & Yes & $\begin{array}{l}\text { Autonomous } \\
\text { Institute }\end{array}$ & No & No & No & Nil & No & Strongest \\
\hline
\end{tabular}




\begin{tabular}{|c|c|c|c|c|c|c|c|c|}
\hline 9 & No & $\begin{array}{c}\text { Autonomous } \\
\text { Institute }\end{array}$ & No & No & No & Nil & Nil & Strongest \\
\hline 10 & Yes & $\begin{array}{c}\text { Autonomous } \\
\text { Institute }\end{array}$ & Yes & Yes & Yes & Minimum & Yes & Strongest \\
\hline 11 & No & $\begin{array}{c}\text { Autonomous } \\
\text { Institute }\end{array}$ & No & No & Yes & Partial & No & Strongest \\
\hline 12 & No & $\begin{array}{c}\text { Autonomous } \\
\text { Institute }\end{array}$ & No & No & No & Nil & Nil & Nil \\
\hline 13 & Yes & $\begin{array}{c}\text { Autonomous } \\
\text { Institute }\end{array}$ & No & Yes & No & Nil & Yes & Partial \\
\hline 15 & No & $\begin{array}{c}\text { Autonomous } \\
\text { Institute }\end{array}$ & No & No & No & Nil & Yes & Partial \\
\hline 16 & No & $\begin{array}{c}\text { Affiliated } \\
\text { College }\end{array}$ & No & Yes & No & Nil & Yes & Partial \\
\hline 17 & No & $\begin{array}{c}\text { Autonomous } \\
\text { Institute }\end{array}$ & No & No & No & Nil & Yes & Nil \\
\hline 18 & No & $\begin{array}{c}\text { Affiliated } \\
\text { College }\end{array}$ & No & No & No & Nil & Yes & Nil \\
\hline 19 & No & $\begin{array}{c}\text { Affiliated } \\
\text { College }\end{array}$ & No & Yes & No & Nil & Yes & Nil \\
\hline 20 & Yes & $\begin{array}{c}\text { Affiliated } \\
\text { College }\end{array}$ & Yes & Yes & No & Minimum & Yes & Nil \\
\hline
\end{tabular}

\subsection{Inferences on the CEOs' background}

9 out of 20 alone possessed a Ph.D.

15 out of 20 had used political influence.

12 out of 20 had the strongest political influence.

2 out of 20 were from state universities. They have facilitated the establishment of postgraduate programs.

4 out of 20 were from affiliated colleges where all policy decisions are undertaken by the government. They have also implemented postgraduate programs.

\subsection{Autonomous institutes}

14 out of 20 were from autonomous institutes where the Board of Governors take implementation policy decisions but major educational policy and administrative policy are taken by the Government. 3 out of 14 colleges (21.42\%) have implemented Postgraduate programs. Only 3 institutions have undertaken global consultancy projects. Only four institutes attempted to get global recognition. 9 Colleges $(64.28 \%)$ have not taken strategic institutional development.

\subsection{The background of corrupt CEOs}

Most of them did not possess the prescribed qualification. They had close links with the politicians to get protection when these CEOs faced investigation. The chairpersons of the governing councils were not aware of the desired growth of the institutes. Many governing council members from the industries did not attend the board meetings. They never compare the performance of these autonomous institutes with similar global institutes. The CEOs were afraid of well-performing faculty members and they decided to curb their growth. The poorly performing coterie provided information on the academic performance of the star performers and they suggest ways to curb their growth. 


\subsection{Focus on the institutional performance}

Assisting the ongoing programs means implementing the approved programs with the needed resources, faculty, and staff and following the curriculum.

Interdisciplinary programs are to be designed to meet the industries' human resources by offering more needed courses from many branches of engineering, sciences, management, mathematics, etc. It should ensure the skills and competencies of the graduates.

Publication of books and papers should be conforming to ISBN standards.

Research projects have to be obtained from the national councils, International Development Agencies, multinational companies, or government departments.

Journals are usually published by universities, institutions, professional associations and conform to ISBN specifications.

The faculty may take a lead to plan international conferences in advanced topics with the approval of the educational administrators and can get cooperation from the national councils or organizations. The evaluation of the CEOs on their initiatives on the educational programs is presented in [Table 2].

Table 2. Initiatives on institutional performance

\begin{tabular}{|c|c|c|c|c|c|c|c|}
\hline CEO & $\begin{array}{c}\text { Assisted } \\
\text { Ongoing } \\
\text { Programs } \\
\end{array}$ & $\begin{array}{c}\text { Interdiscip } \\
\text { linary } \\
\text { Programs } \\
\end{array}$ & $\begin{array}{c}\text { Publications } \\
\text { Books } \\
\text { / Papers } \\
\end{array}$ & $\begin{array}{l}\text { Research } \\
\text { Projects }\end{array}$ & $\begin{array}{c}\text { Development } \\
\text { Projects } \\
\text { Under IDAs }\end{array}$ & $\begin{array}{l}\text { Publication } \\
\text { of Journal }\end{array}$ & $\begin{array}{l}\text { International } \\
\text { Conferences }\end{array}$ \\
\hline 1 (SU) & Yes & Yes & Both & Yes & Yes & Yes & Yes \\
\hline 2 (SU) & Yes & Yes & Papers & Yes & Yes & Yes & Yes \\
\hline $3(\mathrm{~A})$ & Yes & No & No & No & No & No & No \\
\hline $4(\mathrm{~A})$ & Yes & No & Book & No & No & No & No \\
\hline $5(\mathrm{~A})$ & No & No & Papers & Yes & No & Yes & No \\
\hline $6(\mathrm{~A})$ & Partially & No & Papers & Yes & Nil & Yes & Yes \\
\hline $7(\mathrm{~A})$ & Partially & No & Yes & Nil & Permitted & Yes & Yes \\
\hline $8(\mathrm{~A})$ & Partly & No & Yes & Yes & Nil & Yes & Nil \\
\hline $9(\mathrm{~A})$ & Partly & No & Nil & Nil & Yes & Yes & Yes \\
\hline $10(\mathrm{~A})$ & Partly & Partly & Yes & Yes & No & Yes & No \\
\hline $11(\mathrm{~A})$ & Yes & Partly & Book & No & Partly & No & No \\
\hline $12(\mathrm{~A})$ & Yes & No & No & No & No & No & No \\
\hline $13(\mathrm{~A})$ & Yes & Yes & Papers & Yes & No & Yes & Yes \\
\hline $14(\mathrm{~A})$ & Yes & Yes & Papers & Yes & No & Yes & No \\
\hline $15(\mathrm{~A})$ & Yes & No & No & No & No & No & No \\
\hline $16(\mathrm{~A})$ & Yes & Yes & No & No & No & Yes & No \\
\hline 17 (Af) & Yes & Yes & No & Yes & No & No & No \\
\hline 18 (Af) & Yes & Yes & No & No & No & No & No \\
\hline 19 (Af) & Yes & Yes & No & No & No & No & No \\
\hline 20 (Af) & Yes & yes & Yes & Yes & No & Yes & Yes \\
\hline
\end{tabular}

Abbreviations:

Af: Affiliated College to a State University

SU: State University

A: Autonomous Institute 


\subsection{Inferences}

\subsubsection{Autonomous colleges}

Only 3 CEOs permitted interdisciplinary programs.

Only two CEOs (14.28\%) facilitated the publications of books and 4 CEOs $(28.57 \%)$ permitted the publication of papers. 6 out of 14 CEOs facilitated the conduct of research projects. But only 2 CEOs (14.28 \%) approved the conduct of research projects under IDAS. 4 out of 14 CEOs (28.27\%) approved the conduct of international conferences. 9 out of 14 CEOs (64.28\$) facilitated the publication of journals.

Focus on the Faculty Development

Faculty of the colleges and universities are to be developed periodically to meet the challenges of advances in their branches. Quality Improvement Programs (QIP) are offered by various Academic Staff Colleges/Human Resource Development Units and other national institutes. They are funded by the Ministry of Education. Under QIP short-term courses, masters' degree and doctoral degree programs are offered by IITs, NITs, and other wellperforming autonomous colleges. The institutes are expected to depute their faculty members based on their needs. Some faculty members are offered medium-term development programs under various ongoing projects of International Development Agencies (IDAs) and bilateral agreements. Some faculty members are invited to work in foreign universities as interns. Some are invited to present advancements in selected areas through video conferences by foreign universities. The CEOs are expected to select suitable faculty members and permit them to undergo development programs.

Table 3. Focus on the faculty development

\begin{tabular}{|c|c|c|c|c|c|c|c|}
\hline CEO & $\begin{array}{l}\text { Deputing } \\
\text { faculty } \\
\text { for short- } \\
\text { term } \\
\text { courses } \\
\text { under } \\
\text { QIP }\end{array}$ & $\begin{array}{c}\text { Deputing } \\
\text { faculty } \\
\text { under } \\
\text { Global } \\
\text { Bilateral } \\
\text { Programs / } \\
\text { PhD }\end{array}$ & $\begin{array}{l}\text { Permitting } \\
\text { faculty to } \\
\text { accept } \\
\text { nomination } \\
\text { under } \\
\text { foreign } \\
\text { universities } \\
\text { selection } \\
\end{array}$ & $\begin{array}{l}\text { Permitting } \\
\text { faculty to } \\
\text { extend the } \\
\text { program by } \\
\text { availing } \\
\text { leave at } \\
\text { credit }\end{array}$ & $\begin{array}{l}\text { Permitting } \\
\text { faculty to } \\
\text { attend the } \\
\text { sequential } \\
\text { program }\end{array}$ & $\begin{array}{l}\text { Permitting } \\
\text { faculty to } \\
\text { accept to } \\
\text { offer } \\
\text { developmen } \\
\text { t courses in } \\
\text { other } \\
\text { universities }\end{array}$ & $\begin{array}{l}\text { Permitting } \\
\text { faculty to } \\
\text { offer } \\
\text { courses in } \\
\text { foreign } \\
\text { universities } \\
\text { based on the } \\
\text { invitation }\end{array}$ \\
\hline $1(\mathrm{Su})$ & Yes & Yes & Yes & Yes & No & No & Yes \\
\hline $2(\mathrm{Su})$ & Yes & No & Yes & No & No & No & No \\
\hline $3(\mathrm{~A})$ & Yes & No & No & No & Yes & No & No \\
\hline $4(\mathrm{~A})$ & Yes & No & No & No & No & No & No \\
\hline $5(\mathrm{~A})$ & No & No & No & No & No & No & No \\
\hline $6(\mathrm{~A})$ & No & No & No & No & No & No & No \\
\hline $7(\mathrm{~A})$ & Yes & Yes & No & No & No & No & No \\
\hline $8(\mathrm{~A})$ & No & No & No & No & No & No & No \\
\hline $9(\mathrm{~A})$ & Yes & Yes & No & No & No & No & No \\
\hline $10(\mathrm{~A})$ & Yes & No & No & No & No & No & No \\
\hline $11(\mathrm{~A})$ & Yes & Yes & Yes & No & No & No & Yes \\
\hline $12(\mathrm{~A})$ & Yes & No & No & No & No & No & No \\
\hline $13(\mathrm{~A})$ & Yes & No & No & Yes & No & No & No \\
\hline $14(\mathrm{~A})$ & Yes & No & Yes & Yes & Yes & Yes & No \\
\hline $15(\mathrm{~A})$ & Yes & Yes & No & No & No & No & No \\
\hline $16(\mathrm{~A})$ & Yes & Yes & No & No & No & No & No \\
\hline $17(\mathrm{Af})$ & Yes & No & No & No & No & No & No \\
\hline $18(\mathrm{Af})$ & Yes & No & No & No & No & No & No \\
\hline 19(Af) & Yes & Yes & No & No & No & No & No \\
\hline $20(\mathrm{Af})$ & Yes & Yes & No & No & No & No & No \\
\hline
\end{tabular}




\subsubsection{Inferences on autonomous colleges}

12 out of 14 CEOs do not depute the faculty for Ph.D. programs. 4 out of 14 CEOs do depute the faculty for bilateral programs. Only 2 out of 14 CEOs alone permit nomination by the foreign universities, approve the faculty to avail leave at credit to pursue additional semester in foreign countries, and facilitate faculty to attend the sequential program. Only one CEO permits the faculty to offer courses to foreign universities.

Focus on the Institute- Institute- Industry-Government- Society-Partnership

The developed institutes are expected to offer training programs to the engineers of government departments using their expertise. Also, many open invitations are sent by the companies to provide research projects and offer services in selected areas. The competent faculty can bid for the projects through the institutes. Many international development agencies (IDAs) send an invitation to bid for workshops and development programs.

Table 4. Focus on the industry-institute-government -society-partnership

\begin{tabular}{|c|c|c|c|c|c|}
\hline $\begin{array}{c}\text { CEO } \\
\text { Without } \\
\text { PhD }\end{array}$ & $\begin{array}{c}\text { Joint } \\
\text { Bidding for } \\
\text { Projects } \\
\text { under MNCs }\end{array}$ & $\begin{array}{c}\text { Bidding for } \\
\text { Development } \\
\text { Projects under } \\
\text { IDAs based on the } \\
\text { Advertisement } \\
\end{array}$ & $\begin{array}{c}\text { Bidding for } \\
\text { Peripatetic } \\
\text { Programs }\end{array}$ & $\begin{array}{c}\text { Planning to undertake } \\
\text { employee } \\
\text { development projects } \\
\text { offered by Public } \\
\text { Sector Organizations }\end{array}$ & $\begin{array}{l}\text { Bidding for } \\
\text { planning } \\
\text { international } \\
\text { transformation } \\
\text { conferences } \\
\end{array}$ \\
\hline 3 & $\mathrm{No}$ & $\mathrm{No}$ & $\mathrm{No}$ & No & No \\
\hline 4 & No & No & No & No & No \\
\hline 9 & $\mathrm{No}$ & No & Yes & Yes & No \\
\hline 11 & No & No & No & No & No \\
\hline 12 & No & No & No & No & No \\
\hline 14 & No & No & No & No & No \\
\hline 15 & No & No & No & Yes & No \\
\hline 16 & No & No & No & no & No \\
\hline 17 & $\mathrm{No}$ & No & No & No & No \\
\hline 18 & No & No & $\mathrm{No}$ & No & No \\
\hline 19 & No & No & No & No & No \\
\hline
\end{tabular}

\subsubsection{Inferences on autonomous institutes}

CEOs without a Ph.D. degree did not permit the faculty for the following ventures: Joint bidding for projects under MNCs, bidding for projects under IDAs, and international transformation conferences. 2 CEOs permitted the faculty to employee development projects for public sector organizations. Only one CEO was permitted to bid for a peripatetic program under an IDA.

\subsubsection{Focus on global networking}

In this $21^{\text {st }}$ Century, global networking has become essential. This helps to jointly undertake research and development projects. $21^{\text {st }}$ Century India USA knowledge initiative provides many joint programs with leading US Universities. The funds are provided by the Government of India. The CEOs are expected to encourage and develop needed research development projects. Also, under the SWAYAM project, the national institutes are expected to develop mass open online courses to improve the competencies of the faculty members. 
Table 5. Focus on global networking by the CEOs

\begin{tabular}{|c|c|c|c|c|c|c|}
\hline $\begin{array}{c}\mathrm{CEO} \\
\text { without } \\
\text { PhD }\end{array}$ & $\begin{array}{c}\text { Dual } \\
\text { Programs }\end{array}$ & $\begin{array}{c}\text { Joint } \\
\text { Research }\end{array}$ & $\begin{array}{l}\text { Twinning } \\
\text { Programs }\end{array}$ & $\begin{array}{c}\text { Planning } \\
\text { International } \\
\text { Conferences }\end{array}$ & MOOCs & $\begin{array}{l}\text { Courses through } \\
\text { Video Conference }\end{array}$ \\
\hline 3 & No & $\mathrm{No}$ & No & No & No & No \\
\hline 4 & No & No & No & No & No & No \\
\hline 9 & No & No & No & No & No & No \\
\hline 11 & No & No & No & No & No & No \\
\hline 12 & No & No & No & No & No & No \\
\hline 15 & No & No & No & No & No & No \\
\hline 16 & No & No & No & $\mathrm{No}$ & No & No \\
\hline 17 & No & No & No & No & No & No \\
\hline 18 & No & No & No & No & No & No \\
\hline 19 & No & No & No & No & No & No \\
\hline
\end{tabular}

\subsubsection{Inferences}

All the CEOs without Ph.D. qualifications never permitted the faculty for the following: Dual Degree Programs, Joint Research, Twinning Programs, Planning International Conferences, and Courses through Video Conference.

\subsection{Faculty recruitment, sponsoring the faculty for training and conferences, bidding for consultancy works, etc.}

As per AICTE/UGC rules, the best-qualified faculty members are to be selected. The selected faculty have to participate in international conferences, undertake consultancy projects, and share the project gains. The CEOs are responsible for motivating the faculty to engage in all development activities.

Table 6. The decisions are taken by the CEOs in recruitment, facilitating the faculty in participation in the international conferences

\begin{tabular}{|c|c|c|c|c|c|c|}
\hline $\begin{array}{c}\text { CEO } \\
\text { Without } \\
\text { PhD }\end{array}$ & $\begin{array}{c}\text { Decisions } \\
\text { w.r.t } \\
\text { Recruitment } \\
\text { of Highly } \\
\text { qualified and } \\
\text { Accomplished } \\
\text { Candidates }\end{array}$ & $\begin{array}{l}\text { Decisions w.r.t } \\
\text { Recruitment of } \\
\text { less- Qualified } \\
\text { and less } \\
\text { Accomplished } \\
\text { Candidates }\end{array}$ & $\begin{array}{l}\text { Approving } \\
\text { the } \\
\text { participation } \\
\text { in the } \\
\text { international } \\
\text { training } \\
\text { programs }\end{array}$ & $\begin{array}{l}\text { Approving the } \\
\text { participation } \\
\text { in the } \\
\text { international } \\
\text { conferences }\end{array}$ & $\begin{array}{l}\text { Approving } \\
\text { to send the } \\
\text { bid } \\
\text { documents } \\
\text { for } \\
\text { consultancy } \\
\text { works }\end{array}$ & $\begin{array}{l}\text { Approving } \\
\text { the share } \\
\text { of the } \\
\text { gains as } \\
\text { per the } \\
\text { norms }\end{array}$ \\
\hline 1 & Yes & Rarely & $\begin{array}{c}\text { Yes, but } \\
\text { subject to } \\
\text { availability } \\
\text { of funds }\end{array}$ & $\begin{array}{c}\text { Yes, but } \\
\text { subject to } \\
\text { availability of } \\
\text { funds }\end{array}$ & No & No \\
\hline 3 & Yes & $\begin{array}{l}\text { Yes, based on } \\
\text { the political } \\
\text { pressure }\end{array}$ & No & No & No & Partly yes \\
\hline 4 & No & $\begin{array}{l}\text { Yes, based on } \\
\text { the political } \\
\text { pressure }\end{array}$ & No & No & No & Partly yes \\
\hline 9 & No & $\begin{array}{l}\text { Yes, based on } \\
\text { the political } \\
\text { pressure }\end{array}$ & $\begin{array}{l}\text { No, but } \\
\text { prefers the } \\
\text { coterie }\end{array}$ & $\begin{array}{c}\text { No, but } \\
\text { prefers coterie }\end{array}$ & $\begin{array}{l}\text { No, unless } \\
\text { he is } \\
\text { included as } \\
\text { a chief. }\end{array}$ & $\begin{array}{l}\text { A meager } \\
\text { amount } \\
\text { will be } \\
\text { granted }\end{array}$ \\
\hline 11 & No & $\begin{array}{l}\text { Yes, based on } \\
\text { the political } \\
\text { pressure }\end{array}$ & $\begin{array}{c}\text { Yes, based } \\
\text { on the } \\
\text { performance }\end{array}$ & No & No & $\begin{array}{l}\text { As per the } \\
\text { norms }\end{array}$ \\
\hline
\end{tabular}




\begin{tabular}{|c|c|c|c|c|c|c|}
\hline 12 & Yes & $\begin{array}{l}\text { Yes, based on } \\
\text { the political } \\
\text { pressure }\end{array}$ & $\begin{array}{l}\text { Only based } \\
\text { on the } \\
\text { political } \\
\text { pressure. }\end{array}$ & No & No & No \\
\hline 15 & No & $\begin{array}{l}\text { Yes, based on } \\
\text { the political } \\
\text { pressure }\end{array}$ & Yes & No & No & Partly yes \\
\hline 16 (Af) & $\begin{array}{c}\text { NA, } \\
\text { Recruitment is } \\
\text { by state public } \\
\text { service } \\
\text { commission }\end{array}$ & $\begin{array}{l}\text { NA, SPC did on } \\
\text { the political } \\
\text { pressure }\end{array}$ & $\begin{array}{l}\text { Yes, as per } \\
\text { the } \\
\text { government } \\
\text { norms }\end{array}$ & $\begin{array}{l}\text { Yes, as per the } \\
\text { government } \\
\text { norms }\end{array}$ & Yes & $\begin{array}{c}\text { As per the } \\
\text { norms. }\end{array}$ \\
\hline 17 (Af) & Do & Do & Do & Do & Yes & Do \\
\hline 18 (Af) & Do & Do & Do & Do & Yes & Do \\
\hline 19 (Af) & Do & Do & Do & Do & Yes & DO \\
\hline
\end{tabular}

Note: NA -Not applicable

SPC: State Public Service Commission

\subsubsection{Inferences}

4 CEOs of autonomous institutes willfully deviated from the Service Recruitment Rules which is contrary to the established Act. Only two CEOs permitted the recruitment of highly qualified and accomplished candidates but all of them readily permitted the recruitment of less qualified and less accomplished candidates who brought political pressure. The CEOs of affiliated colleges are not empowered to recruit but State Public Service Commission is alone empowered. 3 out of 6 CEOs prefer their coterie for participation in the international training programs. None of the CEOs permit qualified faculty to attend international conferences. One CEO prefers his coterie for all international programs. None of the CEOs permit the faculty to bid for international consultancy projects. A few shares the project gains with the faculty.

\subsubsection{Building a personal empire in the institute}

Accountability: The notion that CEOs who commit crimes against humanity should be held accountable for their actions, either by the Board of Governors or by the government.

Autocracy: A single CEO has the authority to rule over the faculty members in the institute.

Legal accountability: It concerns the mechanisms by which government officials can be held liable for actions that go against established rules and principles.

Political accountability: It means the responsibility or obligation of the government to act in the best interest of society.

Bribe: Offering some money, services, or other valuables, to persuade CEO to get selection, promotion, deputation, etc.

Checks and Balances: This refers to the institutional mechanisms for preventing authority abuse.

Civil Society: A collective term for nongovernmental, mostly non-profit organizations like educational institutes that help their society at the large function while working in advance their own or others' well-being.

Corruption: The abuse of entrusted authority for personal gains.

Embezzlement: The misappropriation of property or funds legally entrusted to the CEO in his or her formal position as an authority.

Favoritism: Refers to the CEO's inclination to prefer coterie over lawful faculty members. 
Governance: The exercise of authority to implement the rules and policies to bring order to the transformation process that allows the institute to develop. Good governance implies a level of accountability and transparency, both of which will help to ameliorate the risk of corruption, a corrosive and destabilizing practice.

Nepotism: Indicates a form of favoritism that involves caste relationships.

Oligarchy: A system of administration in which authority over a relatively defined boundary is concentrated among a small group of faculty or coterie.

Patronage: Refers to the support or sponsorship of a patron. It is used to make appointments for jobs, promotions, or foreign fellowships.

Systemic Corruption: Occurs when corruption is an integrated essential aspect of the institute's administration.

Many CEOs build personal empires by using the public resources of the institute. They also indulge in unethical activities. [Table 7] presents these.

Table 7- Building Personal Empire in the Institute

\begin{tabular}{|c|c|c|c|c|c|c|}
\hline $\begin{array}{c}\text { CEO } \\
\text { Without } \\
\text { PhD }\end{array}$ & $\begin{array}{l}\text { Utilizing the } \\
\text { Resources of the } \\
\text { Institute for his } \\
\text { /her Family } \\
\text { Enterprise }\end{array}$ & $\begin{array}{l}\text { Selection of } \\
\text { Faculty for } \\
\text { Conferences } \\
\text { Based on the } \\
\text { Bribe }\end{array}$ & $\begin{array}{l}\text { Promotion } \\
\text { Based on } \\
\text { The Bribe }\end{array}$ & $\begin{array}{l}\text { Foreign } \\
\text { Training for } \\
\text { the Coterie } \\
\text { or briber }\end{array}$ & $\begin{array}{c}\text { Foreign } \\
\text { Training to } \\
\text { the } \\
\text { Outstanding } \\
\text { Faculty }\end{array}$ & $\begin{array}{c}\text { Demanding } \\
\text { Personal } \\
\text { Service }\end{array}$ \\
\hline 3 & Yes & Yes & Yes & Yes & No & Yes \\
\hline 4 & Yes & Yes & Yes & Yes & No & Yes \\
\hline 9 & Yes & Yes & Yes & Yes & No & yes \\
\hline 11 & Yes & Yes & Yes & Yes & No & Yes \\
\hline 12 & No & No & No & No & No & Yes \\
\hline 15 & No & Yes & Yes & yes & No & No \\
\hline $16(\mathrm{Af})$ & No & No & No & Yes & Yes & No \\
\hline 17 (Af) & No & No & No & Yes & Yes & No \\
\hline 18 (Af) & No & No & No & Yes & yes & No \\
\hline 19 (Af) & No & No & No & Yes & yes & No \\
\hline
\end{tabular}

\subsubsection{Inferences}

4 CEOs of autonomous institutes have indulged in the following unethical activities: Utilizing the Resources of the Institute for their enterprise, selection of faculty based on the bribe, promotion based on the bribe, foreign training for the coterie or briber, and demanding personal services. These CEOs never permitted the outstanding faculty to avail foreign training.

\subsection{Engagement of faculty to develop the academic ecosystem}

The CEO has to conduct monthly faculty meetings for getting information on the growth of knowledge, circulating communication received from AICTE, Ministry, University, or state Governments. The CEO has to plan for new programs or projects in consultation with the faculty members. He is also expected to review the vision and mission of the institute. When some faculty members accomplished a new feat, he has to recognize it and express appreciation. There are many opportunities to undertake sponsored research. These aspects are reviewed. 
Table 8. Engagement of faculty to develop the academic ecosystem

\begin{tabular}{|c|c|c|c|c|c|c|}
\hline CEO & $\begin{array}{c}\text { Getting } \\
\text { Views on the } \\
\text { Global } \\
\text { Advancement } \\
\text { of Theory and } \\
\text { Application }\end{array}$ & $\begin{array}{l}\text { Circulating } \\
\text { the Important } \\
\text { Letters from } \\
\text { the Ministry } \\
\text { of HRD to } \\
\text { the Faculty }\end{array}$ & $\begin{array}{c}\text { Conduct of } \\
\text { Faculty Meeting } \\
\text { to Undertake } \\
\quad \text { New } \\
\text { Interdisciplinary } \\
\text { Programs }\end{array}$ & $\begin{array}{l}\text { Getting the } \\
\text { views of the } \\
\text { faculty to } \\
\text { Expand the } \\
\text { Vision and } \\
\text { Mission of } \\
\text { the Institute }\end{array}$ & $\begin{array}{c}\text { Rewards } \\
\text { and } \\
\text { Recognition } \\
\text { of the High } \\
\text { Performing } \\
\text { Faculty } \\
\text { Members }\end{array}$ & $\begin{array}{c}\text { Readiness to } \\
\text { Undertake } \\
\text { Innovative } \\
\text { Research } \\
\text { Projects }\end{array}$ \\
\hline 3 & No & No & No & No & No & No \\
\hline 4 & No & No & No & No & No & No \\
\hline 9 & No & No & No & No & No & No \\
\hline 11 & No & No & No & No & No & No \\
\hline 12 & No & No & No & No & No & No \\
\hline 15 & No & No & No & No & No & No \\
\hline $\begin{array}{c}16 \\
(\mathrm{Af})\end{array}$ & $\begin{array}{l}\text { A few times, } \\
\text { but the deans } \\
\text { of } P G \\
\text { programs are } \\
\text { made } \\
\text { responsible. }\end{array}$ & Yes & $\begin{array}{l}\text { As per the State } \\
\text { Guidelines }\end{array}$ & $\begin{array}{c}\text { The State has } \\
\text { withheld the } \\
\text { authority. }\end{array}$ & $\begin{array}{c}\text { Orally } \\
\text { appreciated }\end{array}$ & No \\
\hline $\begin{array}{c}17 \\
(\mathrm{Af})\end{array}$ & At times & Yes & $\begin{array}{l}\text { As per the State } \\
\text { Guidelines }\end{array}$ & DO & Do & No \\
\hline $\begin{array}{c}18 \\
(\mathrm{Af})\end{array}$ & At times & Yes & $\begin{array}{l}\text { As per the state } \\
\text { Guidelines }\end{array}$ & Do & Do & No \\
\hline $\begin{array}{c}19 \\
(\mathrm{Af})\end{array}$ & Some times & Yes & $\begin{array}{l}\text { As per the state } \\
\text { guidelines }\end{array}$ & Do & Do & No \\
\hline
\end{tabular}

None of the CEOs made any significant effort to convene any faculty meeting to get their views on global development and advances. Even in the agenda of the Academic Councils such issues are not included. Almost all the CEOs do not circulate the letters issued by the Ministry of Education on very important issues to all faculty members. None of the CEOs of autonomous institutes visualized any advanced interdisciplinary and multidisciplinary graduate programs, hence, they never formally discussed with the faculty. The CEOs of affiliated institutes follow the national policy and the action recommended by the States. None of the CEOs of the autonomous institutes desired to review the vision and mission of the institutes against the global contest after the globalization of the economy. None of the CEOs appreciated the excellence of the faculty performance. None of the CEOs planned any innovative research projects.

Many CEOs take inconsistent decisions, do not have a clear technology concept, fluid participation in the faculty. They never consider oversight. When the underachievement is considered by the ministry, they resort to flight from the scene. They send the substitutes to meet the investigative meeting. 
Table 9. Administration decision making and organized anarchy

\begin{tabular}{|c|c|c|c|c|c|c|c|}
\hline CEO & $\begin{array}{c}\text { Inconsistent } \\
\text { Decisions }\end{array}$ & $\begin{array}{c}\text { ILL- defined } \\
\text { Personal } \\
\text { Preferences }\end{array}$ & $\begin{array}{c}\text { Not having } \\
\text { Clear } \\
\text { Technology }\end{array}$ & $\begin{array}{c}\text { Fluid } \\
\text { Participation }\end{array}$ & Resolution & Oversight & Flight \\
\hline 3 & $\begin{array}{c}\text { Yes, too } \\
\text { often }\end{array}$ & Yes & Yes & Yes & Poor & Nil & Yes \\
\hline 4 & Yes & Yes & Yes & Yes & Poor & Nil \\
t, Yes
\end{tabular}

The CEOs have to encourage the faculty, inspire them and motivate them periodically. They have to focus on creativity. Super leaders should attempt to facilitate the growth of new leaders. He has to ensure the development of high-performing teams. Further, he has to focus on achievement. Rewards are more important not only to enforce high performance but also to encourage the younger faculty members. The CEOS of the affiliated colleges did not venture to undertake innovative research and development projects since such activities are not incorporated in the administration of the institutes. The CEOs of affiliated colleges get clarification from the experts and take appropriate decisions.

\subsection{Leadership style}

The CEOs are very much expected to encourage the faculty, inspire and motivate them. They have to systematically support the leadership development of the faculty. They have conducted a quarterly academic audit or collected the performance and achievement of the departments and place them before the Board of Governors. The data and the information collected were just presented to Board and the CEO made a presentation. Even Board has not appreciated and sent a communication to the high achieving faculty. Rewards are very essential which will motivate other faculty to improve their performance. The decision taken by the CEOs are analyzed and presented in [Table 10] 
Table 10. Review of the leadership style of the CEOs

\begin{tabular}{|c|c|c|c|c|c|c|c|}
\hline CEO & $\begin{array}{c}\text { Encoura } \\
\text { ging the } \\
\text { Faculty }\end{array}$ & $\begin{array}{c}\text { Inspiration } \\
\text { Motivation }\end{array}$ & $\begin{array}{c}\text { Focus on } \\
\text { Creativity } \\
\&\end{array}$ & $\begin{array}{c}\text { Super } \\
\text { Innovation }\end{array}$ & $\begin{array}{c}\text { Focus on } \\
\text { High } \\
\text { Performing } \\
\text { Teams }\end{array}$ & $\begin{array}{c}\text { Focus on } \\
\text { Achieveme } \\
\text { nt }\end{array}$ & Rewards \\
\hline 3 & No & No & No & Never & Never & No & $\begin{array}{c}\text { Only for } \\
\text { coterie }\end{array}$ \\
\hline 4 & No & No & Partly & Never & Sometimes & Yes & $\begin{array}{c}\text { Only for } \\
\text { coterie }\end{array}$ \\
\hline 7 & No & No & No & Never & Nil & No & $\begin{array}{c}\text { Only for } \\
\text { coterie }\end{array}$ \\
\hline 8 & No & No & No & Never & Nil & No & $\begin{array}{c}\text { Only for } \\
\text { coterie }\end{array}$ \\
\hline 9 & No & No & Rarely & Never & Very little & $\begin{array}{c}\text { Yes, Instant } \\
\text { Results }\end{array}$ & $\begin{array}{c}\text { Only for } \\
\text { coterie }\end{array}$ \\
\hline 11 & No & No & Rarely & Rarely & At times & $\begin{array}{c}\text { Yes, Instant } \\
\text { results }\end{array}$ & $\begin{array}{c}\text { Only for } \\
\text { coterie }\end{array}$ \\
\hline 12 & Yes & Sometimes & No & No & At times & Yes & Nil \\
\hline 15 & Never & Never & Never & Never & Rarely & Always & Never \\
\hline 16 (Af) & Yes & At times & Some times & No & At times & Yes & $\begin{array}{c}\text { Oral } \\
\text { appreciation }\end{array}$ \\
\hline 17 (Af) & Yes & Yes & Frequently & No & Sometimes & Always & Some times \\
\hline 18 (Af) & Yes & Yes & At times & No & $\begin{array}{c}\text { Some } \\
\text { times }\end{array}$ & Yes & Some times \\
\hline 19 (Af) & Yes & Yes & Yes & No & At times & Yes & Sometimes \\
\hline
\end{tabular}

Most of the CEOs of autonomous institutes (87.5\%) did not encourage the faculty, did not focus on creativity and innovation, and did not inspire and motivate the faculty. They also never felt the need for super leadership. Some of them (62.5\%) at times, focused on the high performance for preparing annual reports which will be placed on the Parliament. Whereas, the CEOs of affiliated institutes consistently encouraged the faculty, focused on creativity, high performance, and achievement. They orally appreciated the high performers.

\subsection{Extreme disruptions caused by some CEOs of autonomous institutes}

The CEOs have to follow the decisions of the duly constituted selection committee in the case of the selection of faculty members to various posts. Also, they have to pay the salary as per the pay scale fixed by the government. When the faculty submits the paper to various conferences, if the paper is selected for presentation, they need to be deputed as per the AICTE norms. The decision has to be based on the rules and acts only. The CEOs do not have any discretion.

The decisions taken by ten CEOs of autonomous institutes are presented in the case of outstanding faculty members. 
Table 11. Review of the decisions taken by the CEOs of Autonomous Institutes concerning faculty members

\begin{tabular}{|c|c|c|c|c|c|c|}
\hline CEO & $\begin{array}{l}\text { Suspending } \\
\text { the faculty for } \\
\text { trivial reasons }\end{array}$ & $\begin{array}{l}\text { Dismissing the } \\
\text { faculty for } \\
\text { trivial reasons }\end{array}$ & $\begin{array}{l}\text { Denying } \\
\text { sponsorship to } \\
\text { present papers in } \\
\text { the international } \\
\text { conferences }\end{array}$ & $\begin{array}{l}\text { Denying the } \\
\text { approval to } \\
\text { the } \\
\text { outstanding } \\
\text { faculty } \\
\text { undergo the } \\
\text { training in the } \\
\text { foreign } \\
\text { universities }\end{array}$ & $\begin{array}{l}\text { Offloading } \\
\text { the projects } \\
\text { to } \\
\text { commercial } \\
\text { agencies } \\
\text { own } \\
\text { through } \\
\text { bidding }\end{array}$ & $\begin{array}{l}\text { Denying to } \\
\text { offer posts } \\
\text { even though } \\
\text { the selection } \\
\text { committee } \\
\text { approved }\end{array}$ \\
\hline 1 & Yes & Yes & Yes & Yes & Yes & Yes \\
\hline 2 & Yes & Yes & Yes & Yes & Yes & Yes \\
\hline 3 & Yes & Yes & Sometimes & Sometimes & No & Sometimes \\
\hline 4 & Yes & No & Sometimes & Yes & Yes & Yes \\
\hline 5 & Yes & Yes & Always & Always & $\begin{array}{c}\text { Never } \\
\text { allows the } \\
\text { bidding }\end{array}$ & Yes \\
\hline 6 & Maximum & Always & Always & Always & Always & Always \\
\hline 7 & Yes & Yes & Yes & Yes & Always & Yes \\
\hline 8 & Yes & Yes & Yes & Yes & Yes & Yes \\
\hline 9 & Yes & Yes & Yes & Always & Yes & Always \\
\hline 11 & Yes & Yes & Yes & Yes & Yes & Always \\
\hline 16 & No & No & $\begin{array}{l}\text { As per the norms } \\
\text { and funds } \\
\text { availability }\end{array}$ & $\begin{array}{l}\text { As per the } \\
\text { norms }\end{array}$ & Never & Never \\
\hline 17 & No & No & Do & Do & Do & Do \\
\hline 18 & No & No & Do & Do & Do & Do \\
\hline 19 & No & No & Do & Do & Do & Do \\
\hline
\end{tabular}

All the CEOs of autonomous institutes recklessly suspended the faculty members for trivial reasons whereas no CEO of an affiliated institution resorted to suspend or dismiss the faculty for trivial reasons. $90 \%$ of the CEOs of autonomous institutes denied permission to the outstanding faculty to train in foreign universities even though they rooted their application through the proper channel. They also offloaded the projects won by the faculty external commercial agencies. They tried to stop the posting even after the duly constitutes selection committee approved their placement. Whereas none of the CEOs of affiliated institutes indulged in such low-level activities. The suspended faculty have been reinstated after the inquiry committee disproved the charges. The dismissed faculty appealed to the court and got judgment in their favor. In this process, the institute lost a large sum of money.

\subsection{Institutionalizing corruption in various activities}

Many CEOs have mastered the art of emblement of public money and they are also protected by the Board. The corrupt practices are concealed very much and they are sometimes identified by the audit parties but no action has been taken as long as these corrupt CEOs are in power. 
Table 12. Activities of 12 CEOs are synthesized and presented

\begin{tabular}{|c|c|c|c|c|c|c|c|}
\hline CEO & $\begin{array}{c}\text { Corruption } \\
\text { in Civil } \\
\text { Works }\end{array}$ & $\begin{array}{c}\text { Corruption } \\
\text { in Faculty } \\
\text { Recruitment }\end{array}$ & $\begin{array}{c}\text { Corruption } \\
\text { In Project } \\
\text { Execution }\end{array}$ & $\begin{array}{c}\text { Corruption in } \\
\text { Deputation to } \\
\text { Externally } \\
\text { Funded } \\
\text { Development } \\
\text { Programs }\end{array}$ & $\begin{array}{c}\text { Corruption } \\
\text { in } \\
\text { Purchases }\end{array}$ & $\begin{array}{c}\text { Corruption } \\
\text { in Project } \\
\text { Approval }\end{array}$ & $\begin{array}{c}\text { Corruption } \\
\text { in Air- } \\
\text { Travel }\end{array}$ \\
\hline 4 & Nil & At times & Yes & At times & At times & At times & Nil \\
\hline 5 & Yes & Always & Always & Always & Always & Always & Always \\
\hline 6 & $\begin{array}{c}\text { Mastered } \\
\text { the art }\end{array}$ & Always & Always & Always & Always & Always & Always \\
\hline 7 & Yes & Always & Always & Always & Always & Always & Always \\
\hline 8 & Yes & Always & Always & Always & Always & Always & Always \\
\hline 9 & Nil & Yes & Yes & Nil & Some & Many- & Always \\
times & times & Nil & Nil \\
\hline 11 & Nil & Yes & Nil & Sometimes & Nil & Nil \\
\hline 12 & Nil & Nil & At times & Nil & Nil & At times & Nil \\
\hline 15 & Nil & Mastered art & Yes & Sometimes & Nil & Nil & Nil \\
\hline 16 & Nil & Nil & Nil & Nil & Nil & Nil & Nil \\
\hline 17 & Nil & Nil & Nil & Nil & Nil & Nil & Nil \\
\hline 18 & Nil & Nil & Nil & Nil & Nil & Nil & Nil \\
\hline 19 & Nil & Nil & Nil & Nil & Nil & Nil & Nil \\
\hline
\end{tabular}

The CEOs of affiliated institutes never indulged in any corrupt activities in construction, faculty recruitment, project execution, externally funded projects, purchases, project approval, or air transport. 44.44 CEOs of autonomous institutes have indulged in corrupt activities in construction. Also, the same has been deducted by the audit party but no action was taken. $77.78 \%$ of CEOs indulged in corrupt practices in faculty recruitment. This resulted in low performance. This set of CEOs also extended corrupt practices in project executions, the deputation of faculty to externally funded projects, purchases, project approval, and air travel.

\subsection{Dealing with court cases}

Most of the time, most affected faculty members approach honorable courts to get legal solutions. Only a few win the cases. Many of others are intimated by the CEOs like transfer, suspension, etc. They resort to bribing the lower court officials in tampering with the cause list or displacing the court bundle. They also offer some other incentives to withdraw the cases. The actions of the CEOs are identified and presented in [Table 13].

Table 13. Review of decisions and actions by CEOs concerning court cases

\begin{tabular}{|c|c|c|c|c|c|c|}
\hline CEO & $\begin{array}{c}\text { Use of } \\
\text { Coercion to } \\
\text { Withdraw } \\
\text { the Case }\end{array}$ & $\begin{array}{c}\text { Tampering } \\
\text { with the } \\
\text { Cause Listing }\end{array}$ & $\begin{array}{c}\text { Use of funds to } \\
\text { bribe the lower } \\
\text { court officials in } \\
\text { concealing the } \\
\text { case bundle }\end{array}$ & $\begin{array}{c}\text { Tampering } \\
\text { the } \\
\text { Documents } \\
\text { With false } \\
\text { Information }\end{array}$ & $\begin{array}{c}\text { Providing } \\
\text { incentives to } \\
\text { withdraw the } \\
\text { cases }\end{array}$ & $\begin{array}{c}\text { Creating false } \\
\text { decision } \\
\text { documents as } \\
\text { the direction } \\
\text { from the Board }\end{array}$ \\
\hline 5 & Yes & Always & Always & Always & Sometimes & Always \\
\hline 6 & Certainly yes & Yes & Yes & Yes & Some times & Always \\
\hline 7 & Yes & Yes & Yes & Yes & Yes & Yes \\
\hline 8 & Yes & Yes & Yes & Yes & Yes & Yes \\
\hline 9 & Yes & Yes & Yes & Yes & Yes & Yes \\
\hline 11 & Yes & Yes & Yes & Yes & yes & Yes \\
\hline
\end{tabular}




\subsubsection{Inferences}

All the six CEOs indulged in all sorts of corrupt practices stated above concerning court cases.

\subsubsection{Dealing with court orders}

A few of the most corrupt CEOs do not accept court judgments or orders which leads to contempt of court and punishment. They also appeal to a bench and get a stay. Later they leave the office. Such behaviors reveal the bipolar disorder and megalomania characters. Even some of the CEOs have undergone legal programs and completed the degree. A few never decided to implement the court orders and also escaped from the punishments due to the contempt of the case. The actions taken by some of the CEOs are analyzed and presented in [Table 14].

Table 14. Review of the reactions due to court orders

\begin{tabular}{|c|c|c|c|c|}
\hline CEO & Court Cases & Court Orders & Violating Court Orders & Final Outcome \\
\hline 5 & $\begin{array}{c}\text { Tried to prolong the } \\
\text { cases by various tactics }\end{array}$ & $\begin{array}{c}\text { Do not implement the } \\
\text { court order }\end{array}$ & $\begin{array}{c}\text { Completes the tenure } \\
\text { and leaves safely }\end{array}$ & $\begin{array}{c}\text { Some cases are } \\
\text { prolonged in the labor } \\
\text { court }\end{array}$ \\
\hline 6 & $\begin{array}{c}\text { Tried to prolong the } \\
\text { cases by various tactics }\end{array}$ & $\begin{array}{c}\text { Do not implement the } \\
\text { court order }\end{array}$ & $\begin{array}{c}\text { Gets punishment for } \\
\text { contempt of the court }\end{array}$ & $\begin{array}{c}\text { Gets stay completes } \\
\text { the tenure and leaves } \\
\text { the institute. }\end{array}$ \\
\hline 11 & $\begin{array}{c}\text { Got the job under an } \\
\text { IDA and left the } \\
\text { institute. }\end{array}$ & $\begin{array}{c}\text { The successor } \\
\text { implemented the court } \\
\text { order. }\end{array}$ & Not applicable & Not applicable \\
\hline
\end{tabular}

\subsubsection{Inferences}

Only three CEOs who are intensively involved in meeting the severe penalty given by the honorable judges are considered. They indulge in unfair labor practices and finally face the punishments. They not only lose their reputation but also the institute loses its high reputation. The government bears all court-related expenditures. Taxpayers' money is wasted.

Modus Operandi of corrupt CEOs in autonomous institutes

(a) Getting the CEOs to post through false documents, bribing, and political influence.

(b) Creating a group of low performing coterie

(c) Including corrupt subordinates through lateral recruitment.

(d) Institutionalizing corrupt practices in purchases, building construction and maintenance, recruitment, foreign travel, offloading the projects to external agencies, etc.

(e) Trying to sabotage the court cases

(f) Denying permission to the high-performing faculty members to attend international conferences, undertaking outstanding training and development programs under bilateral agreements even though the faculty applied through the official channel, not granting pay as per the government orders/ approved schemes, joining an intern in overseas universities, bidding for global projects, accepting rewards, etc.

This model leads to "Corruptocracy". 
Table 14. Comparison of bureaucracy with Corruptocracy

\begin{tabular}{|c|c|c|}
\hline Factor & Bureaucracy & Corruptocracy \\
\hline A division of labor & Based on functional specialization & Based on the discretion of the CEO \\
\hline A system of rules & $\begin{array}{c}\text { Covering the rights and duties of } \\
\text { employees }\end{array}$ & $\begin{array}{c}\text { The faculty cannot claim any rights } \\
\text { but they have to perform the duties }\end{array}$ \\
\hline Hierarchy & Well defined authority & Based on the discretion of the CEO \\
\hline A system of procedures & For dealing with a work situation & $\begin{array}{c}\text { Flexible, CEO decides based on the } \\
\text { relationships with the faculty }\end{array}$ \\
\hline $\begin{array}{c}\text { Interpersonal relations } \\
\text { Selection and promotion of } \\
\text { faculty members }\end{array}$ & $\begin{array}{c}\text { Based only on technical } \\
\text { competence }\end{array}$ & $\begin{array}{c}\text { Based on the personal relationships } \\
\text { with the CEO on the services rendered } \\
\text { to the CEO }\end{array}$ \\
\hline
\end{tabular}

Comparison of CEO of an affiliated institute with that of a CEO in an autonomous institute. The decision-making process of CEOs of affiliated institutes could be compared to those of CEOs of autonomous institutes to assess the problems.

Table 15. Comparison of CEO of an affiliated college and that of an autonomous college

\begin{tabular}{|c|c|c|}
\hline Factor & CEO of an Affiliated College & CEO of an Autonomous College \\
\hline $\begin{array}{l}\text { Promotion of Faculty } \\
\text { Members }\end{array}$ & $\begin{array}{l}\text { By seniority and satisfactory } \\
\text { performance; should possess } \\
\text { the prescribed qualification. }\end{array}$ & $\begin{array}{l}\text { Selection should be based on the highest } \\
\text { quality and accomplishment. Many CEOs do } \\
\text { not qualify fully. }\end{array}$ \\
\hline $\begin{array}{c}\text { Faculty Development } \\
\text { under QIP, ISTE, Foreign } \\
\text { Universities, etc. }\end{array}$ & $\begin{array}{l}\text { As per the norms, there will } \\
\text { be no discretion to stop }\end{array}$ & $\begin{array}{l}\text { Mostly Discretion. Can deny nomination in } \\
\text { the last minute even the application is routed } \\
\text { through proper channel. }\end{array}$ \\
\hline $\begin{array}{c}\text { Initiatives on the } \\
\text { Institutional Performance }\end{array}$ & $\begin{array}{l}\text { Follows the government } \\
\text { decisions }\end{array}$ & $\begin{array}{l}\text { Has full autonomy but the Board has to } \\
\text { approve and later the MHRD }\end{array}$ \\
\hline $\begin{array}{l}\text { Undertaking Development } \\
\text { projects under IDAs }\end{array}$ & $\begin{array}{l}\text { Has to get the government } \\
\text { approval }\end{array}$ & Has to get Board's approval \\
\hline $\begin{array}{l}\text { Permission to Participate } \\
\text { in the International } \\
\text { Conferences }\end{array}$ & $\begin{array}{c}\text { Based on the norms and } \\
\text { subject to availability of funds }\end{array}$ & $\begin{array}{c}\text { Discretion of CEO but the Board has to } \\
\text { approve. }\end{array}$ \\
\hline $\begin{array}{c}\text { Industry-Institute- } \\
\text { Government- Society- } \\
\text { Partnership } \\
\end{array}$ & $\begin{array}{l}\text { As per the government's } \\
\text { norms }\end{array}$ & $\begin{array}{l}\text { Discretion but the Board has to approve and } \\
\text { the budget has to be approved by the Ministry } \\
\text { of Education. }\end{array}$ \\
\hline Global networking & As per the Government norms & $\begin{array}{l}\text { Discretion of CEO, but the Board has to } \\
\text { approve. }\end{array}$ \\
\hline Building Personal Empire & Forbidden & Many did it even though it is against the rules \\
\hline $\begin{array}{c}\text { Engagement of Faculty to } \\
\text { develop Academic } \\
\text { Ecosystem }\end{array}$ & $\begin{array}{l}\text { No restriction but approval is } \\
\text { required from the government }\end{array}$ & $\begin{array}{l}\text { Should be based on the vision and mission. } \\
\text { The CEO can take needed initiatives and get } \\
\text { ratification from the Board. }\end{array}$ \\
\hline $\begin{array}{l}\text { Administrative Decision } \\
\text { Making }\end{array}$ & $\begin{array}{l}\text { CEO gets all clarity from the } \\
\text { departments. } \\
\text { Avoids organized Anarchy }\end{array}$ & $\begin{array}{l}\text { CEO may use his discretion since it is not } \\
\text { controlled by the Society's Act of } 1860 \text { or } \\
\text { Memorandum of Administration (MoA). }\end{array}$ \\
\hline Leadership Style & $\begin{array}{l}\text { Depends on the vision of the } \\
\text { CEO but can't pulldown the } \\
\text { faculty easily }\end{array}$ & $\begin{array}{l}\text { Discretion, but many misused the authority in } \\
\text { collusion with the Chairman. }\end{array}$ \\
\hline Academic Decisions & $\begin{array}{l}\text { Based on the problems and } \\
\text { follows the rules. }\end{array}$ & $\begin{array}{l}\text { Uses discretion but wrong decisions could be } \\
\text { challenged in the court }\end{array}$ \\
\hline $\begin{array}{c}\text { Corruption in Academic } \\
\text { Activities }\end{array}$ & $\begin{array}{l}\text { Almost nil, and has to follow } \\
\text { the rules. }\end{array}$ & $\begin{array}{c}\text { Discretion takes many unethical decisions. } \\
\text { Faculty are coerced. } \\
\text { Coterie is getting the benefits. }\end{array}$ \\
\hline Court Cases & $\begin{array}{l}\text { Strictly follows the court } \\
\text { orders }\end{array}$ & $\begin{array}{l}\text { Many failed to implement the court orders but } \\
\text { faced contempt of the court. Finally got stayed } \\
\text { and left after the completion of the tenure. }\end{array}$ \\
\hline
\end{tabular}


The CEOs of affiliated colleges are following the rules and norms. The CEOs of the autonomous colleges misuse the discretion and finally face the court orders but get stay and leaves the institute.

Almost all faculty associations resist autonomy. Autonomy has been brought to facilitate quick advances in educational programs. This is defeated by unethical CEOs who got selection through an inefficient recruitment process.

\subsection{The ultimate loss to the state}

(a) The loss to knowledge capital development.

(b) Financial loss.

(c) Forced to employ external consultants to undertake development works.

(d) The loss to the local industries due to improper curriculum and poor-quality graduates.

(e) The loss to the star faculty who are prevented from achieving-innovations.

(f) They may even resign and leave the country.

(g) Competitiveness of the state/ region/ nation is retarded.

\subsection{Evaluation of achievement of the autonomous institutes}

Government constitutes a high-power committee once in ten years to study the performance of the autonomous institutes. A team of four specialists study the accomplishments and prepare a report to the government. The standing committee of parliament visits the institute once in ten years and submits a report to the Ministry of Education. These reports highlight the overall performance and the contribution made to the nation. These reports focus on the macro-level performance without any specific prescribed goal.

\subsection{Suggested recruitment process}

(a) Selection of CEO

The highest educational qualification, accomplishment, and in-depth expertise in the domain have to be given maximum importance. There must be a well-designed application listing the proposed vision, mission, transformation process, interdisciplinary programs, strategic planning, globalization, global networking, faculty development, integrity, planning interdisciplinary and multidisciplinary research projects, entrepreneurship development, developing high performing team, planning to generate revenue through consultancy projects, etc. The candidates have to produce medical certificates that they are having good physical and mental health. Short-listed candidates have to be interviewed on their planning for transformation methods. The candidates have to be rank-ordered. They should follow the highest ethical standards.

(b) Their focus on faculty development has to be evaluated and the best proposals have to be given importance.

(c) Their planning for Industry-Institute-Government-Society Partnership should be evaluated.

(d) Their focus on global networking has to be carefully reviewed. 
(e) Their methods of recruitment of faculty have to be checked.

(f) They have to propose strategies for curbing the development of the personal empire.

(g) They have to create an appropriate academic ecosystem for high performance.

(h) They have a plan for the engagement of the faculty through the academic ecosystem.

(i) They should plan various development centers like consultancy center, continuing education center, research and development, publication center, innovation center, etc.

(j) They have to display appropriate leadership to improve the performance of the faculty and students.

(k) They have to focus on a corruption-free environment.

(l) Return on investment has to be calculated.

\subsubsection{The role of the board of governors}

(a) Review the performance every quarter.

(b) Get feedback from the faculty members.

(c) Analyze the feedback and take remedial measures.

\subsubsection{Major focus on the performance of the CEOs}

(a) Whether the CEO has focused on the institute's vision, mission, performance, culture, and values?

(b) Whether high-performing teams have been developed?

(c) Whether the institute has achieved its mission in creating human and knowledge capital?

(d) Whether the institute has served the SMMEs by training and providing solutions to the problems through consultancy projects?

(e) Whether the institute have a suitable academic ecosystem?

(f) Whether the graduates meet the desired skill and competency standards?

(g) Whether the faculty have contributed to the knowledge capital by innovative intellectual products at global standards?

(h) Whether the contribution of the autonomous institute can be compared with of similar institute elsewhere?

\section{Conclusion}

The major problem in the cancerous growth of corruptocracy is due to poor-quality CEOs. From this focused research the following steps are recommended to select an outstanding faculty for a CEO's post:

(a) Every effort has to be taken to select the best CEO based on the in-depth analysis of their background, accomplishment vision, and mission. 
(b) The application form should call for the applicant's vision, mission, transformation process, development of interdisciplinary and multidisciplinary graduate, postgraduate and doctoral programs,

(c) Leadership qualities focus on diverse, global faculty development programs,

(d) His fast achievement in entrepreneurship development, supporting high performing faculty teams, and outstanding contributions in human and knowledge capital development,

(e) His integrity, ethics, achievement motivation, reputation, etc. are to be checked,

(f) Outstanding accomplishment and in-depth expertise in the domain have to be given importance for selection.

(g) His/her capacity in planning industry-institute-government-national laboratories has to be assessed.

(h) The Board of Governors has to establish a standing committee on various focused development activities and review the performance.

(i) The standing committees have to curb the development of personal empire, accelerating the growth of coteries and systematically suppressing the growth of high-performing faculty teams,

(j) Focus on establishing research parks and creating an academic ecosystem for highperforming faculty teams, establishing publication centers, technical journals, monographs, etc.

(k) There should be a grievance redressal process so that the problems can be solved timely.

(1) The Board should establish outstanding goals based on the market demands and support the process of getting funds for implementing them.

(m) If the performance is very low, there should be appropriate remedial measures through inquiry.

The above suggestions are made to develop more responsible educational organizations which will contribute to the nation's competitiveness.

As the growth of a nation is very much dependent on knowledge capital and human capital, further research is recommended.

\section{References}

[1] Aishalabi "Corruption in higher education appears to be on the rise globally," (2013), https://www.chronicle.com/article/corruption-in-higher-education-appears-to-be-on-the-rise-globally-reportsays/

[2] A. Kamp, "Engineering education in a rapidly changing world," Tu Delft University, Center for Education, (2016)

[3] A. Pajazite and S. Gerguri, "Towards university ethics and academic excellence: Addressing and fighting corruptions,"

[4] A. Lonsotale, "Corruption in higher education," https://integrityaction.org

[5] A. L. Osipian, "Corruption in higher education: Does it differ across the nation and why?" ERIC, Research in Comparative and International Education, vol.3, no.4, pp:345-365, (2008), https://eric.ed.gov/?id=EJ891953

[6] A. L. Osipian, "Higher education corruption in world media: Prevalence, patterns, and forms, (2013) 
[7] A. Kizalic, "Corruption in higher education fiction or reality," Inter Logos Central University ITC, (2015)

[8] H. Bathelt and R. Gibson, "Learning in organized anarchies: The nature of technological search processes at trade fairs," Regional Studies, vol.49, pp.985-1002, (2015)

[9] Creating a Cycle of Incompetence, EDC, pp.16-17, (2012)

[10] D. Beanland and R. Hadgraft, "Engineering education: Transformation and innovation," Malborne-Victoria: RMIT University Press, (2013)

[11] Davidson, "Facing up to the c-word corruption in higher education," theconversation.com/facing-up to-the-cword-corruption-in-higher-education-23854, (2005)

[12] V. Deepa, "Higher education in India is at risk," (2018)

[13] D. G. Faust, "The role of the university in a changing world," Boston: Harvard University, (2010)

[14] A. Easton, "Decision making: A short course for professionals," vol.1, New York, John Wiley

[15] G. Mohamedbhai, "Higher education: A hotbed of corruption,"

(2015) http//www.insidehighered.com/blogs/world-view/higher-education-hotbed-corruption

[16] G. Mohamedbhai, "Fraud and corruption in higher education; why, how and what role for leadership," Accra, Ghana, International Conference Leadership for a Changing Public-Private Higher Education Funding Landscape, pp.18-20, October, (2017)

[17] G. J. Daviss, G. E. Kirk, and D. A. Nethercot, "Educating engineers for the $21^{\text {st }}$ Century," London: Royal Academy of Engineering, (2007)

[18] E. G. Guba and Y. S. Lincoln, "Fourth Generation of Evaluation,” Newbury Park, Sage

[19] J. Washburn, "University, inc.: The corporate corruption of higher education," Reed Business Information, A Division of Reed Elsevier Inc, (2006)

[20] J. Hallak and M. Poisson, "Corrupt schools, corrupt universities: What can be done?" Paris: UNESCO: International Institute for Educational Planning, (2007)

[21] J. Attich, "The manifestation of corruption in higher education: The role of the university administration, (2015)

[22] K. Ren, "Fighting against academic corruption: A critique of recent policy development in China," Higher Education Policy, vol.25, no.1, pp.19-38, (2012), https://link.springer.com/article/10.1057/hep.2011.20

[23] K. L. Ochse, "Preventing corruption in the education system," Division 42 Sector Project: Developing and Testing of Strategies and Instruments for Prevention of Corruption in the Education System, GTZ, Germany, (2004)

[24] P. Kennedy, "How to combine research options. Practical triangulation," (2009)

[25] K. Rostiashvili, "Corruption in the higher education system of Georgia," Transnational Crime and Corruption Center (TRACCC), (2004)

[26] J. Kusum and S. Kusum, "Corruption: it's silent penetration into the Indian education system," Journal of Education and Practice, vol.4, no.1, pp.30-35, (2013)

[27] N. R. F. Mailer, "Problem-solving discussions and conferences: Leadership, methods, and skills," New York, Me Graw-Hill

[28] M. Weber, "Bureaucracy," Retrieved from https://www.toppr.com/guides/fundamentals-of-economics-andmanagement/evolution-of-management-thought/bureaucratic-theory-by-max-weber/

[29] D. McFarland and C. Gomez, “4 organizational analysis," (2013), Coursera. pp.60-77, https://www.dropbox.com/s/78ktuqc11mcc4kz/Organizational_Analysis_Book_2016.pdf?dl=0

[30] Measures to Prevent Corruption, www.toolkit.inceenite/TNEEcms/updates/1038/Preventing_Corruption_in_The_Education_System.pdf

[31] J. Martin, "A garbage can model of the psychological research process," American Behavioral Scientist, vol.25, pp.131-151, DOI: 10.1177/0002766428102500203

[32] M. Weber, "German Politics," London: Faber and Faber Ltd, pp.128

[33] M. Bassis, "A primer on the transformation of higher education in America," National Institute of Learning Outcome Assessment, (2015) 
[34] M. D. Cohen, J. G. March, and J. P. Olsen, “A garbage can model of organizational choice,” Administrative Science Quarterly, vol.17. no.1, pp.1-25, DOI:10.2307/2392088

[35] J. Olsen, "The origins of the gargage can model," (2011), https://www.youtube.com/watch?v=raTM7OSSQ8k

[36] R. Mukherjee, "Indian education system: What needs to change?" UN Pleaders, (2007)

[37] R. Graham, "The global state of the art in engineering education," New Engineering Education, Massachusetts Institute of Technology, Boston, (2018)

[38] R. H. Hall, "The concept of bureaucracy: An empirical assessment," The American Journal of Sociology, vol.69, no.1, pp.33

[39] S. Coughian, "Corruption and bribery in the classroom," (2013)

[40] S. Neelakantan, "Fighting corruption at India's universities," Public Radio International (PRI), (2010)

[41] M. Smirnova, "Country report on corruption in higher education and research in the Russian higher education," (2013)

[42] J. Steen, J. A. Ford, and M. Verrey, "Symbols, sublimes, solutions, and problems: A garbage can model of megaprojects," Project Management Journal, vol.48, pp.117-131, (2017)

[43] S. P. Heyneman, K. H. Anderson, and N. Nuraliyeva, "The cost of corruption in higher education," Rentseeking, Public Sector-Higher Education. Comparative Education Review

[44] V. Thanikachalam, "Enhancing institutional governance beyond the society's act of 1860. (Steps to Improve Autonomous Institutes' Administration through Board of Governance)," Journal Engineering of Education Transformations, Special Issue, (2016)

[45] V. Thanikachalam, "Building institute's culture and values to facilitate excellent high performing institute, Journal of Engineering and Technology Education, vol.10, no.1, pp-18-22, (2016)

[46] V. Thanikachalam, "Performance management and turnaround mechanism of poorly performing institutes," Journal of Engineering Education Transformations, Journal of Engineering Education Transformations, vol.32, no.2, pp-46-54, (2018)

[47] V. Thanikachalam, "Institutional transformation and development in engineering education to meet volatility, complexity, and ambiguity (VUCA)," $5^{\text {th }}$ International Conference on Transformations in Engineering Education, Theagarajar College of Engineering, Madurai, Tamil Nadu, India, (2018)

[48] V. Thanikachalam, "Educational management ecosystem for facilitating the development of professional competencies of CEOs in higher education," $5^{\text {th }}$ International Conference on Transformations of Engineering Education, Thegarajar College of Engineering, Madurai, India, (2018)

[49] V. Thanikachalam, "Academic excellence through an improved ecosystem and faculty engagement," $5^{\text {th }}$ International Conference on Transformations on Engineering Education, Theagarajar College of Engineering, Madurai, India, (2018)

[50] V. Thanikachalam, "Strategies for eliminating corruption in engineering education and fostering excellence in human capital development," $5^{\text {th }}$ International Conference on Transformations in Engineering Education, Theagarajar College of Engineering, Madurai, India, (2018)

[51] V. Thanikachalam, "Enhancing interdisciplinary research in engineering education (IDREE)," $5^{\mathrm{TH}}$ International Conference on Transformations on Engineering Education, Theagarajar College of Engineering, Madurai, India, (2018)

[52] V. Thanikachalam, "Desired educational ecosystem in the fast-growing educational institutes in India," APInternational Conference on Transformations in Engineering Education, SRM University, Amaravati, AP, India, (2018)

[53] V. Thanikachalam, "Advanced educational system to undertake international consultancy projects in the engineering institutes under global economy," AP-International Conference on Transformations in Engineering Education, SRM University, Amaravati, AP, India, (2018)

[54] V. Thanikachalam, "Dynamic process for enhancing engineering faculty competence in India," APInternational Conference on Transformations in Engineering Education, SRM University, Amaravati, AP, India, (2018) 
[55] Transparency International, Corruption by topic- Education, https://www.transparency.org/en/

[56] Triangulation-Better Evaluation, (2018), Retrieved from https://www.betterevaluation.org/en/evaluationoptions/triangulation

[57] UNDP, (2011), Fighting Corruption in the Education Sector, Methods, Tools, and Good Practices, Bureau for Development Policy, One United Nations Plaza, New York. https://www.undp.org/publications/fightingcorruption-education-sector

[58] United States Institute of Peace, (2010), Governance, Corruption, and Conflict - A Study Guide Series on Peace and Conflict for Independent Learners and Classroom Instructors, United States Institute of Peace, Washington, D.C, USA

[59] V. Valentino, "Managing corruption in Moldova, thesis: Master of public administration in international development at the Kennedy school of government (KSG), Harvard University

[60] W. Kigotho, “Corruption is eroding higher education's benefits," University World News, Issue 290, (2013), www.universityworldnews.com/article.php?-201310060

[61] W. K. Hoy and C. G. Miskel, "Educational administration, theory, research, and practice," ADO, Sixth Edition, Boston, Massachusetts

[62] W. J. Kresse, "International corruption in higher education: Analysis of causes and reforms at the secondlargest institution of higher education," Files eric.ed.gov/full text/EJ1139512, Spring 2017, Issue-1, pp.35-40

[63] G. W. Tierney and N. S. Sabharwal, "Academic corruption: Culture and trust in Indian higher education," International Journal of Educational Development, vol.55, pp.30-40, July, (2017), DOI:10.1016/j.jedudev.2017.05.003

[64] World Bank (2014) Future Development, Six Strategies to Fight Corruption, blogs

[65] World University News, Corruption is Eroding Higher Education's Benefits, https://www.universityworldnews.com/post.php?story=20131001160142405

[66] Y. Zhu and A. Kindarto, "A garbage can model of government IT project failures in developing countries: The effects of leadership, decision structures, and team competence," Government Information Quarterly, vol.33, pp.629-637, (2016) 


\section{Author}

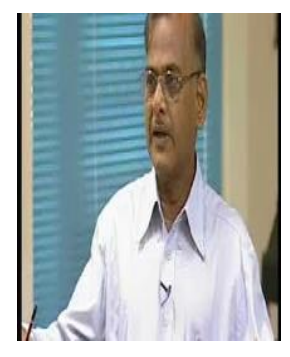

\section{Thanikachalam Vedhathiri}

B.E., 1968, Civil Engineering, University of Madras

M. Tech., 1970, Soil Mechanics and Foundation Engineering, Indian Institute of Technology, Madras

Ph.D., 1975, Filter Design for Earth and Rockfill Dams, University of Madras

M.S., 1988, Instructional System Technology, Indiana University, Bloomington, USA

FIE, FIGS, FFIUCEE, Former Professor and Head, Center for International Affairs, National Institute of Technical Teachers Training and Research, Chennai, India. 